\title{
The value of long-term environmental monitoring programs: an Ohio River case study
}

\author{
Timothy W. Lohner • Douglas A. Dixon
}

Received: 12 December 2012 / Accepted: 11 May 2013 /Published online: 29 May 2013

(C) The Author(s) 2013. This article is published with open access at Springerlink.com

\begin{abstract}
As a subset of environmental monitoring, fish sampling programs have been an important part of assessing the potential impacts of water withdrawals and effluent discharges on fish populations for many years. New environmental regulations often require that adverse environmental impacts to fish populations be minimized. Without long-term field data, population evaluations may incorrectly indicate adverse impacts where none exist or no impact where one is likely to occur. Several electric utility companies have funded the Ohio River Ecological Research Program, which has been in existence for over 40 years and consists of fish, habitat, and water quality studies at multiple power plant sites on the mainstem Ohio River. Sampling includes seasonal night-time electrofishing and daytime beach seining at three upstream and three downstream locations near each plant. The long-term nature of the program allows for the establishment of aquatic community indices to support evaluations of technology performance, the collaborative development of compliance metrics, and the assessment of fish population trends. Studies have concluded that the Ohio River fish community has improved in response to better water quality and that
\end{abstract}

T. W. Lohner $(\bowtie)$

American Electric Power,

1 Riverside Plaza,

Columbus, OH 43215, USA

e-mail: twlohner@aep.com

D. A. Dixon

Electric Power Research Institute,

3420 Hillview Ave,

Palo Alto, CA 94340, USA power plant fish entrainment and impingement and thermal discharges have had little or no measureable impact. Through collaboration and the use of longterm data, $\$ 6.3$ million in monitoring costs have been saved during recent fish impingement studies. The ability to access a multiyear fish abundance database, with its associated data on age, growth, and fecundity, improves the quality of such evaluations and reduces the need for extensive field sampling at individual locations.

Keywords Ohio River · Electric utility · Fish · Long term $\cdot$ Monitoring $\cdot$ Electrofishing

\section{Introduction}

While long-term environmental studies provide valuable insights into ecology, environmental change, and natural resource management (NRC 1990; Thomas et al. 2005; Lovett et al. 2007; Lindenmayer et al. 2012), it is often difficult to maintain such programs. Tinkle (1979), when summarizing the challenges of longterm monitoring, remarked that funding agencies can be reluctant to support long-term projects. More recently, Bolgrien et al. (2005), when commenting on the assessment of great river ecosystems, found that there is an alarming lack of information on these systems, reflecting the inadequacies of monitoring strategies. The assessment of rivers is challenging because the scope of the studies must be relevant to stakeholders' concerns, and it is politically challenging to incorporate data collection and assessment into decision-making processes (Bolgrien et al. 2005). 
As a subset of environmental monitoring, fish sampling programs have been an important part of assessing the potential impacts of water withdrawals and effluent discharges on fish populations for many years (Barnthouse et al. 1988; Fremling et al. 1989; USGS 1999; Gammon and Simon 2000; Jacobson et al. 2004; Daniels et al. 2005; Thomas et al. 2005; McClelland et al. 2012). Such monitoring programs are typically conducted by state and federal agencies, but it is not unusual for corporations, such as electric utilities, to conduct similar studies (Jennings et al. 1995; Danila 2000; Hickman and Olmsted 2001; Hickman and Brown 2002). However, in economically challenging times, it can be difficult to justify the continuance of a long-term monitoring program, regardless of the funding source.

Investigators have addressed these issues in their reviews of environmental monitoring programs and have posed the question of whether or not monitoring should even be considered "science," suggesting that the merits of these programs may be in doubt (Tinkle 1979; Lovett et al. 2007). Thomas (2005) acknowledged the need for economic accountability and asked "how long should a long-term river study be," noting that it is often necessary to balance data requirements with economic resources, implying that monitoring programs may be discontinued if financial resources are not available. Yet, a single misinformed decision to discontinue a monitoring program can eliminate the value of years of data when it is needed most and the associated costs of failing to detect and address early environmental problems can be enormous. The National Research Council Committee on a Systems Assessment of Marine Environmental Monitoring (NRC 1990) noted that degraded environments can be mitigated, but some degradation may be irreparable. The Committee also noted that public opposition and anger may increase with the news that fish have been harmed and those who are responsible may be blamed for neglect or short-sightedness.

Despite the challenges of maintaining a viable research program, several electric utility companies have funded a long-term fish monitoring program on the Ohio River for over 40 years. The Ohio River Ecological Research Program (ORERP) maintains the largest freshwater database on the potential effects of power plant water withdrawals and discharges in the world, yielding invaluable information for power companies while documenting key ecological changes in one of the nation's most important rivers. This paper will present and discuss how a long-term fish monitoring program on the Ohio River allows electric utility companies to distinguish between the many possible factors that can affect fish populations and how, by collaborating on such studies, the companies have maximized the value of this program.

\section{The Ohio River ecological research program}

A typical power plant uses on average, from 38 to 720 million gallons of water a day, depending on whether or not it uses open-cycle (once-through) or closed-cycle cooling (US EPA 2009). Due to this need for water, most power plants are located on rivers, lakes, oceans, and other water bodies and, as a consequence, can impact nearby fish populations. For example, coolingwater intake systems have the potential to impact aquatic organisms through impingement and entrainment (Lohner et al. 2000; Perry et al. 2002; Barnthouse 2013). Impingement is the entrapment of aquatic organisms on intake screens, while entrainment is the passing of aquatic organisms through these screens into the power plant cooling system. Impingement generally impacts adult and juvenile life stages of aquatic organisms, while entrainment impacts early life stages, such as eggs and larvae. Cooling water discharges may also affect fish populations due to the increased thermal loading to the receiving stream (Langford 1990; EPRI 2008a) and waste water discharges may affect water quality and, subsequently, harm exposed fish populations (Wisniewski 2000).

Environmental legislation and regulations require that power plants be designed with the best technology available to minimize adverse environmental impacts to fish populations. $\S 316$ (b) of the Clean Water Act (CWA) requires that "the location, design, construction and capacity of cooling water intake structures reflect the best technology available for minimizing adverse environmental impact." § 316(a) of the CWA requires that temperature standards "assure the protection and propagation of a balanced, indigenous population of shellfish, fish, and wildlife in and on the body of water into which the discharge is to be made." Obviously, there is great incentive for electric utility companies to avoid harming fish populations in the waterbodies from which water is withdrawn and into which water is discharged. 
There are over 40 steam electric power plants located along the length of the Ohio River that utilize the river as a source of cooling and process water (Fig. 1). While these plants can have an effect on fish populations, there are over 600 other permitted discharges to the river under the National Pollutant Discharge and Elimination System (Emery et al. 2003), which also affect water quality and associated fish populations. In addition, 20 lock and dam structures exist on the Ohio River, which have altered the habitat and restrict fish movement throughout the river (Nielsen et al. 1986; Thomas et al. 2005). Drinking water suppliers and other industrial facilities also withdraw large amounts of water from the river. During such withdrawals, fish can become impinged or captured on the intake screens and larval fish can be entrained through the facility. If sufficient numbers of fish are impinged or entrained, populations may be adversely impacted. All of these activities can affect river fish populations. In addition, and probably most significantly, climate effects, such as droughts, floods, and severe temperature changes, can also have serious impacts on Ohio River fish populations (Coutant 1992; Gammon and Simon 2000).

Due to the legal consequences of failing to comply with environmental rules and regulations, it is important for power companies to demonstrate no harm when there is none, recognize when there is harm, and to distinguish between potential power plant effects and all other impacts. As a result, the ORERP was initiated in 1970 to gather information on the potential impacts of power plant operation on Ohio River biota. The program was originally sponsored by ten electric utilities, but many other utilities have participated in the program on a continuous or periodic basis from 1970 thru 2010 (Fig. 2), and since 2002, the program has been managed by the Electric Power Research Institute (EPRI), a nonprofit organization that conducts research for the benefit of the public and its member companies.

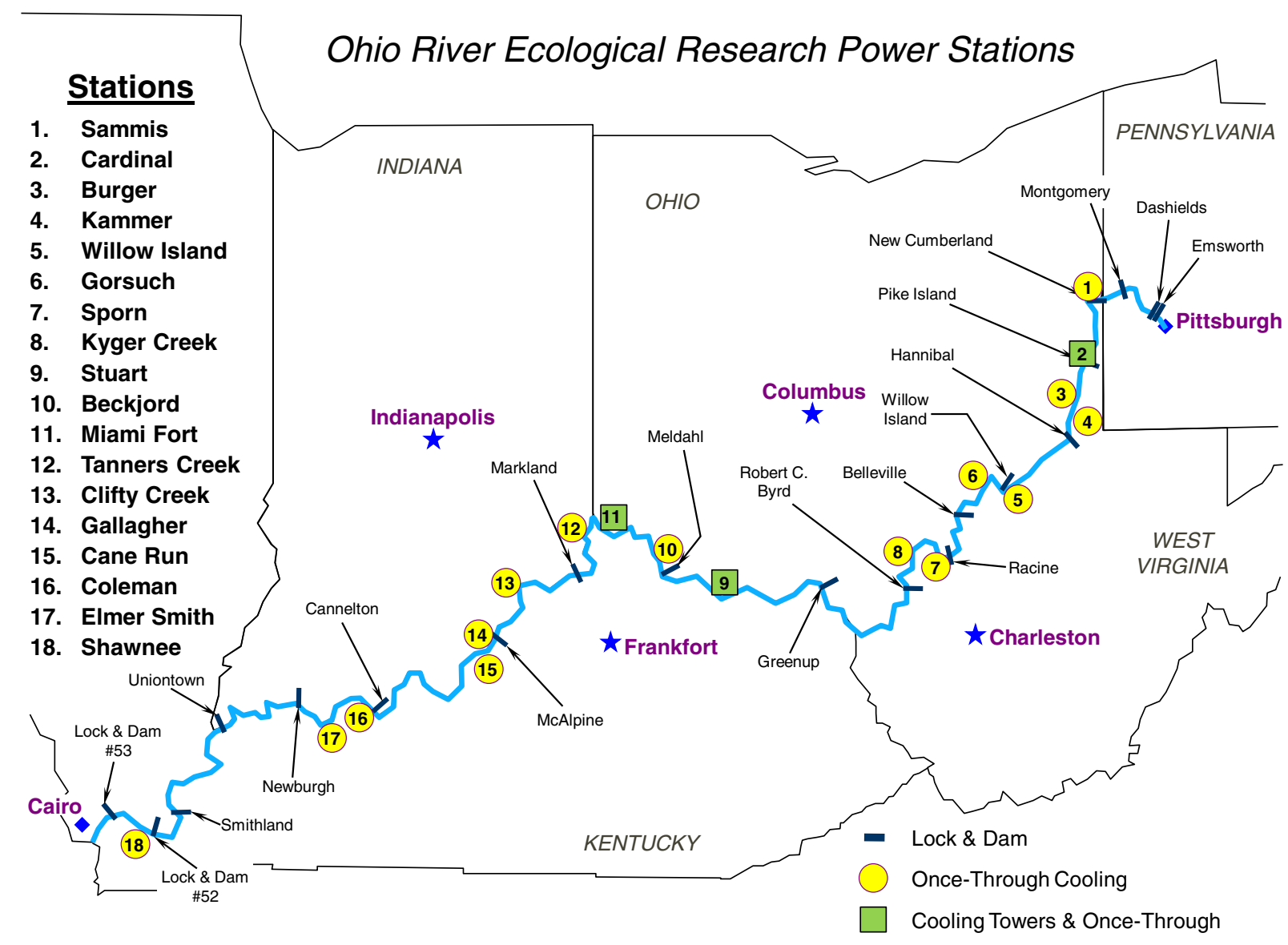

Fig. 1 Map of Ohio River ecological research power stations 
All 18 of the plants that have been in the program are coal-fired facilities that use once-through cooling and represent over $70 \%$ of the facilities on the river with such systems. Their locations cover the entire length of the river (Fig. 1) and extend from river kilometer (rkm) 85.3 near Toronto, OH, USA, downstream to rkm 1,522.4 near Paducah, KY, USA. The number of generating units at each plant ranges from one to ten, with generating capacities ranging from 213 to $1,830 \mathrm{MW}$ and design cooling water intake capacities ranging from 606 to $3,962 \mathrm{~m}^{3} \mathrm{~min}^{-1}$ (EPRI 2009b; King et al. 2010). Some of the plants have been sampled every year since the inception of the program, while others have been sampled intermittently or only once or twice over the past $40+$ years (Fig. 2).

\section{Fish sampling on the Ohio River}

During the early years of the ORERP, adult and juvenile fish were sampled by electrofishing, seining, trawling, hoop netting, and gill netting techniques (WAPORA 1971, 1974, 1978); however, adult and juvenile fish sampling was reduced over the years to electrofishing and seining to improve sampling efficiency and reduce costs. Beginning in 1991, electrofishing was conducted during the night to improve sampling effectiveness and to make the procedures consistent with those of Ohio EPA (OEPA 1989; Sanders 1991).

Descriptions of specific fish sampling techniques can be found in Lohner et al. (2000) and EPRI (2007). Fish are sampled at each power plant during three sampling periods, typically in June, August, and October. Six sampling stations are located at each power plant (three upstream and three downstream), with the exception of the Shawnee Plant, where there are two upstream and four downstream sampling locations. Temperature, dissolved oxygen (DO), conductivity, water clarity (Secchi disk depth), river flow, and other water quality data are measured during each collection. For the electrofishing zones, temperature is measured at the upper end of the zone, near shore

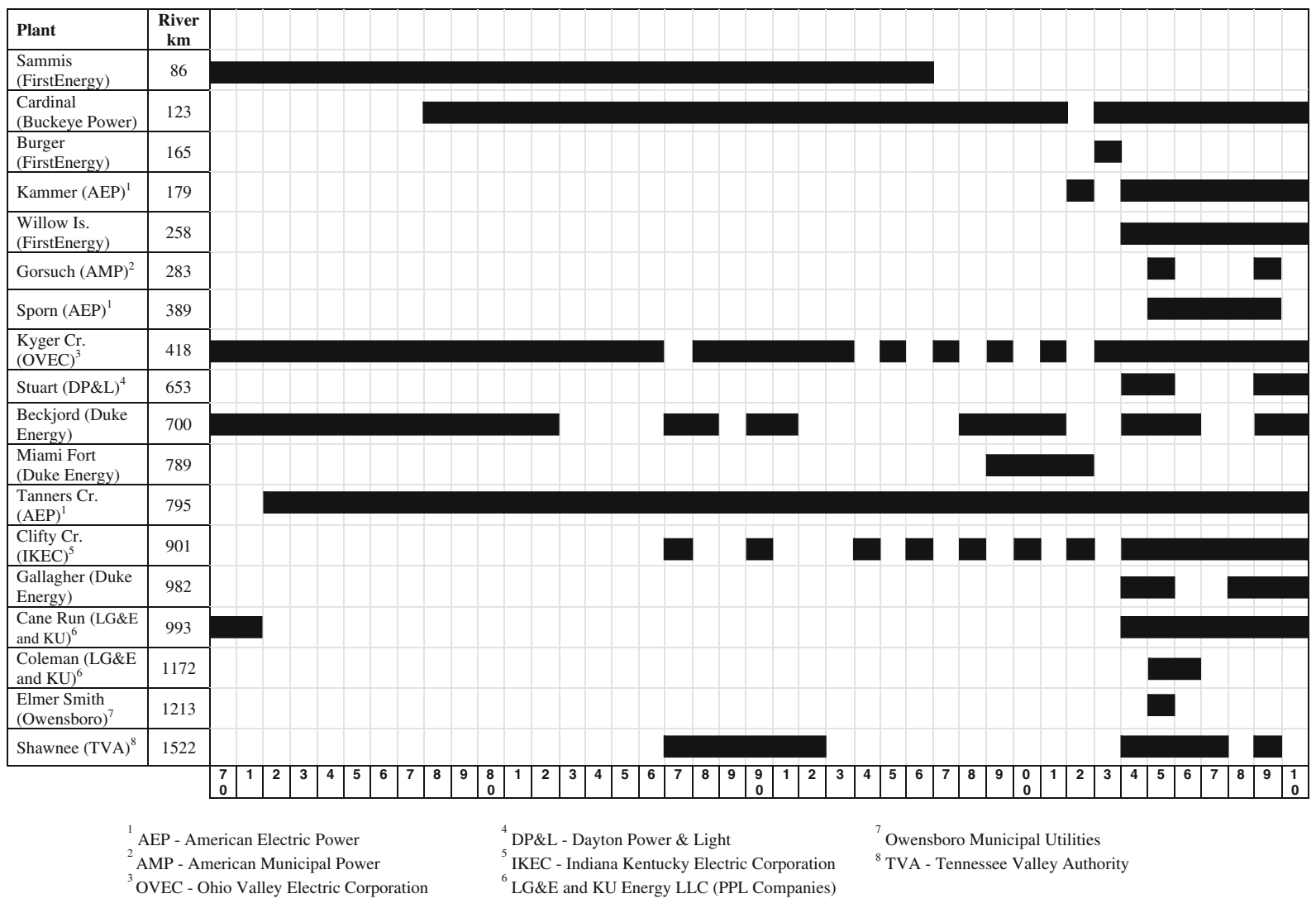

Fig. 2 ORERP power plant participation 
( $\sim 0.5 \mathrm{~m}$ depth) and off shore ( 2.0 $\mathrm{m} \mathrm{depth})$ at the middle of the zone, at the downstream end of the zone, and within the thermal discharge. DO, conductivity and Secchi measurements are made at the upstream end of each zone. Water quality parameters are also measured at each seine location, as well as within the thermal discharge. All parameters, except Secchi depth, are measured at mid-depth.

Water temperature, DO, and conductivity are measured using electronic meters. Water clarity is measured using a standard Secchi disk. Since electrofishing is conducted at night, Secchi depths are measured using a spotlight. The temperature thermistors are factory-calibrated prior to the field season and crosschecked against an NBS traceable thermometer before each trip and at the beginning of each sampling day. The DO sensors are factory-calibrated prior to the field season and cross-checked against the Winkler method before each trip and once during each survey. In addition, the DO sensor is calibrated prior to each measurement. The conductivity sensors are factorycalibrated prior to the field season and cross-checked against a known standard before each trip and at the beginning of each sampling day.

With regards to the fish collection data, abundance, biomass, catch per unit effort (CPE) values, species richness, modified Index of Well-Being (IWBmod), Ohio River Fish Index, Shannon diversity indices, as well as the coefficient of community index, used to measure similarity of the fish fauna among power plant sites (Johnson and Brinkhurst 1971), are calculated for each electrofishing sample. Because CPE (by number), IWBmod, and diversity values can be strongly influenced by large numbers of emerald shiner (Notropis atherinoides) and gizzard shad (Dorosoma cepedianum), these parameters are calculated both with and without them. Specific details on how these indices were determined can be found in EPRI (2012b).

During 2007-2009, a winter sampling program was conducted at eight of the facilities, which included adult and juvenile fish sampling from January through March, with the primary objective of documenting potential attraction to the thermal discharges during the winter months. Except for the season involved, all aspects of winter sampling were consistent with the methods followed during the standard seasonal surveys.

The sample results are published in an annual report, which is shared not only with the utility sponsors but also with state and federal environmental agency staff as well as local universities (EPRI 2007, 2008b, 2009a, 2011, 2012a, b).

\section{Initial short-term sampling results}

A review of fish monitoring data collected upstream and downstream of a facility during a single year may indicate significant differences; however, it would not be possible to determine the overall impacts of these results without long-term or multiyear data. For example, data collected from the AEP Tanners Creek Plant during 2006, indicated that CPE values for all fish types (detritivores, invertivores, and piscivores) were much higher upstream of the plant than downstream of the facility; however, it was not immediately possible to determine the cause of this effect or whether or not this difference was a one-time event or an ongoing occurrence (EPRI 2008b). Another example is provided by the analysis of sauger (Sander canadensis) CPEs, which decreased from 1991 to 2003 and recovered shortly thereafter, yet a definitive reason for the decline was never determined (EA 2004). In both cases, without data from the previous or following years, it would not have been possible to determine the relative magnitude of the CPE changes or if they were indicative of long-term changes in the river. Regardless of the reasons for the declines and subsequent recoveries, the long-term data of the ORERP provides the context upon which to judge whether or not there have been changes in the river fish populations near the power plants.

Once long-term trends have been identified, their occurrence can be shared with resource agencies for further investigation or action. McClelland et al. (2012), Pegg and McClelland (2004), O'Hara et al. (2008), Carpenter (1998), Elliot (1990), and Walters and Martell (2004) all note the value of long-term monitoring and how the data can be used to support fishery management decisions. Examples include setting recreational creel limits, documenting improvements in water quality and fisheries following the implementation of sewage treatment, habitat restoration, and other water quality improvement projects.

Franklin (1989) notes that any ecological phenomena with a return time of more than a few years should be monitored with long-term studies. Without observing these phenomena over a long period of time, it 
may not be possible to observe them or even discover that they occur. For example, a review of electrofishing survey data collected at the Cardinal Plant revealed that in 1997 and 2001 the number of fish collected increased from a typical number of below 10,000 fish to above 30,000 in 1997 and over 80,000 in 2001 (Fig. 3; EA 2004). These increases were due to large numbers of young gizzard shad. Gizzard shad are highly fecund, episodic reproducers whose spawning success is affected by environmental factors, such as floods or rapid temperature changes (Eisele and Malaric 1978). Had the monitoring not been done at the facility over a several year period, these "episodic" events would likely not have been detected. Conversely, had a 316(b) study been conducted during either of those 2 years, large numbers of gizzard shad would have been entrained or impinged on power plant intake screens, possibly necessitating mitigation. The installation of costly mitigation measures would have been based on "episodic" events, rather than multiyears studies, which might have indicated lower numbers of shad in the river and less urgency for mitigation.

Over the years, significant changes in the weather and river flows have, from time to time, significantly altered the results of the monitoring program. Based on these occurrences, it has generally been found that, "the populations of these species... are more likely to be affected by changes in factors such as habitat, water quality, and the occurrence of floods, droughts, and temperature extremes, rather than the minor changes resulting from entrainment-impingement losses" (Perry et al. 2002). Short-term sampling studies, without the benefit of statistical analyses to determine relationships with weather and other phenomenon, would not reach these same conclusions.

\section{Trend analyses}

Due to the breadth of the ORERP, it is possible to use the data to conduct assessments of past trends in the current fish populations. Franklin (1989) noted that "many ecological processes take place over relatively long time periods, typically much longer than the normal grant [period] of three years." In addition, it is often necessary to conduct long-term studies in order to separate subtle changes in population patterns from the year-to-year variability or "noise," which is often large compared to the magnitude of the trend. Changes in fish population dynamics over time provide such an example. Van Hassel et al. (1988), in their review of Ohio River fisheries data collected from 1973 to 1985 , found that 22 species of fish significantly increased in abundance over the 12-year period and that catches of seven pollution-tolerant species declined. Their findings provided strong evidence of positive changes in the Ohio River fishery in response to water quality improvements due to improved industrial and municipal treatment facilities.

Similarly, Thomas et al. (2005) confirmed the value of long-term, consistent monitoring programs in detecting trends in Ohio River fish populations through their analysis of fish assemblages collected from Ohio River navigational dam lock chambers from 1957 to 2001. During this time period, 377 fish collections were made using rotenone, resulting in the
Fig. 3 Abundance of fish collected in Cardinal Plant electrofishing surveys

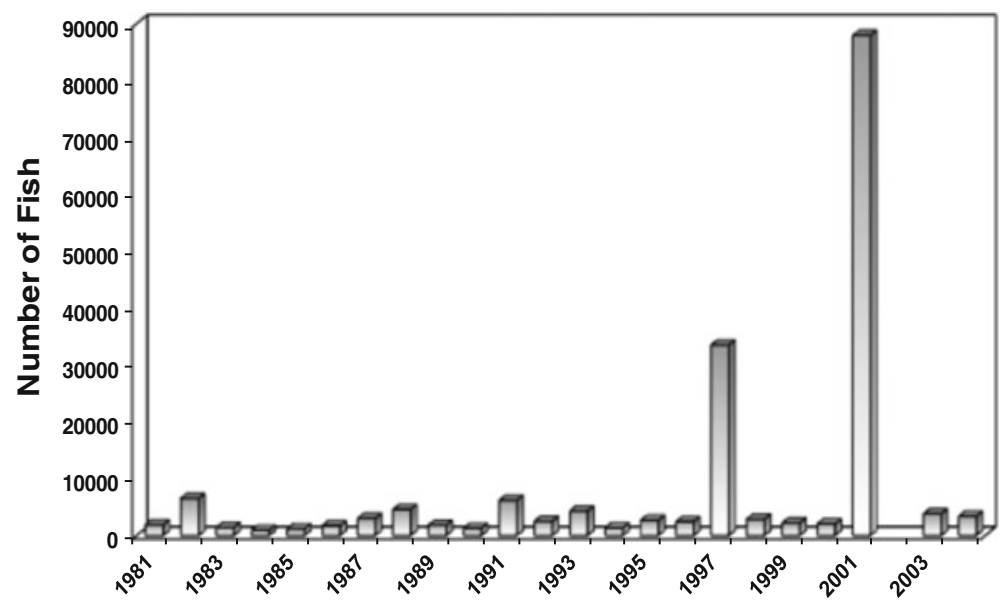


collection of nearly three million fish, representing 116 taxa, including 7 hybrids, in 19 families (Thomas et al. 2005). Water quality measurements taken during those collections indicated an improvement in water quality over time, with higher dissolved oxygen and $\mathrm{pH}$ levels contributing the most to the overall improvements. Thomas et al. (2005) reported "temporal changes in fish assemblage condition, guild structure, and species structure, indicat[ing] an improvement in Ohio River lock chamber fish populations (and presumably those of the river) from 1957 to 2001." In both the Van Hassel and Thomas studies, these analyses could not have been done without the long-term and extensive database.

The improvements in Ohio River fish populations noted by Thomas et al. (2005) and Van Hassel et al. (1988) coincided with the marked improvement of Ohio River water quality over the past 50 years. During this same time period, new power plants were built, which significantly increased the amount of water withdrawn for cooling, thermal loadings to the river, and the discharge of waste water. With the increased withdrawal of cooling water, the magnitude of fish entrainment and impingement also increased; yet, despite these increases in water use and discharge, there was no measureable decline of fish populations.

\section{Modeling}

With the collection of additional ecological data (age, growth, and fecundity), models can be applied to the data not only to establish current trends in the river fish populations, but to project what those populations might be under various impact scenarios. For example, the ORERP electrofishing database from 1977 to 2003, the ORSANCO electrofishing database from 1991 through 2003 and the ORSANCO lock chamber rotenone database from 1958 through 2003 have been used to assess the potential impacts of fish impingement on the river's fish populations (Lohner et al. 2000; Perry et al. 2002). Several fish species were selected for evaluation and several life history parameters (age, growth, fecundity, and age-specific survival) were used to project the populations in different river pools forward for a 50-year time period with and without fish impingement. The projected changes ranged from a $3 \%$ decrease for white bass (Morone chrysops) in the Robert Byrd pool to a $57 \%$ increase for freshwater drum (Aplodinotus grunniens) in the same pool when the effects of the power plants were removed (Perry et al. 2002). Since caution must be used when interpreting such results, a comparison was also made between the predicted increase and the observed population variability as documented in the electrofishing data over the past several years. Overall, the modeling results suggested that improvements in the fish populations with the power plant effect removed was unlikely in 16 of the 22 modeled scenarios (Perry et al. 2002). In other words, the predicted population increase was within the level of normal variability for the fish populations. Not only did these results demonstrate that, in most cases, fish populations are not significantly impacted by power plant operation but that they can also be used to evaluate the effect that new intake technologies may have on fish populations.

\section{Financial value}

The cost to participate in a monitoring program, such as the ORERP, is low when compared to the cost of complying with new 316(a) or (b) regulations. When averaged over the 2007-2009 sampling period, the annual monitoring cost at each plant was $\sim \$ 49,000$. Participating utilities were able to take advantage of an additional cost savings of approximately $35 \%$ due to their affiliation with EPRI. More significant cost savings could also be achieved if the monitoring was done in a collaborative manner, as was done by the owners of 15 power plants from 2005 through 2007 (EPRI 2007, 2008b, 2009a).

In 2005, a fish impingement study (EPRI 2009b; King et al. 2010) was planned and implemented by a number of Ohio River utilities to comply with the Phase II Rule of $\$ 316($ b) of the Clean Water Act that was finalized in 2004 (69 Fed. Reg. 41576, July 9, 2004, since remanded by EPA because of judicial review). The Phase II Rule allowed the rate of impingement to be determined by several options, among them was to conduct new studies or to use data from nearby "like" facilities. The utilities decided to use a hybrid approach, combining new studies and using data from "like" facilities, which was to be a unique study based on its collaborative approach, standardized design, and the sharing of data among the utilities (EPRI 2009b; King et al. 2010). 
The multifacility impingement study designed for the ORERP participants was based on a relatively new concept in survey design methods called "model based estimation" or "small area estimation" (Rao 2003). The model based approach is in contrast to traditional or design-based methods of estimation, which use only data from the target population to compute estimates for the target population. That is to say, only data from a particular plant is used to estimate total impingement at that facility. In the ORERP "modelbased" sampling design, all information for the 15 power plants participating in the program was pooled to estimate the model parameters and variance terms.

An intuitive way to think of the model-based approach is as follows. In the single plant approach, if impingement samples are collected once every 1 or 2 weeks, there is no impingement information to interpolate between sample events. With the modelbased sampling design, information collected from other plants during a given estimating period helps define the pattern between sample events at a single plant. Improved interpolation between sample events leads to a better estimate of total impingement at an individual plant. This multiplant approach only works if different plants have similar seasonal trends. An analyses of the historical impingement data for the Ohio River plants showed that the seasonal trend was sufficiently similar among the plants to support the model-based sampling design (EPRI 2009b). Not only did use of the model-based sampling design result in improved impingement estimates, but fewer samples were needed to make these estimates. Instead of being sampled weekly or biweekly over a 2-year period for a total of up to 84 samples, the plants were sampled approximately 45 times, resulting in significant cost savings. Due to the reduced monitoring frequency, the pooling of resources, and the economy of scale, the monitoring costs per participant were lower than if each pursued the studies on their own, resulting in a total savings of $\$ 6.3$ million for all of the facilities combined.

The use of historical 316(b) and long-term fish monitoring data not only allows for the development of innovative study designs, but it can also be used to determine the economic value of reducing impingement over a long period of time. The Phase II §316(b) regulations contained national performance requirements mandating reductions of fish impingement mortality at cooling water intake structures relative to that encountered at a baseline facility with no impingement controls. However, the rule also allowed a facility to demonstrate that it met site-specific standards in lieu of national standards due to compliance costs being "significantly" greater than the economic value of the derived benefits.

To conduct such a study, the impingement monitoring data from historical studies conducted at 14 cooling water intakes on the Ohio River during the 1970s and early 1980s were obtained. As is typical for the results of most impingement monitoring studies, annual impingement estimates were dominated by a relatively small number of species. Gizzard shad accounted for almost $75 \%$ of the total annual impingement followed by freshwater drum and skipjack herring (Alosa chrysochloris). Together, these three species accounted for almost $96 \%$ of annual impingement.

Based on a careful review of the annual impingement estimates, seven fish species were selected to be the focus of the economic benefits valuation for the study: gizzard shad, freshwater drum, channel catfish (Ictalurus punctatus), emerald shiner, white bass, bluegill (Lepomis macrochirus), and white crappie (Pomoxis annuralis). These species were selected to be both representatives of species typically impinged at Ohio River facilities and of economic benefit categories, such as commercial, recreational, or forage base.

To assign an economic value to impingement reduction, losses were converted to estimated equivalent fishery yield using the equivalent yield model or to equivalent biomass production using the production foregone model, two models well accepted by the scientific community and used by USEPA in the 316 (b) rulemaking. The monetary value of these biological benefits was then calculated with standard resource economics methodologies that are consistent with those used by USEPA (EPRI 2006).

For the study, it was estimated that the annual benefit of compliance at a hypothetical Ohio River power plant would be $\$ 11,620$ (EPRI 2006). If compliance technology began operation in 5 years and continued for an additional 21 years, the net present value of the total lifetime economic benefits of the reduction in impingement would be $\$ 133,843$ per hypothetical plant (EPRI 2006). The value of this work is that these values can now be compared to the cost of complying with the $316(\mathrm{~b})$ rule to determine if retrofitting or 
installing new intake technologies is cost effective or the costs "greatly" exceed the benefits.

Based on the above fish valuation studies for existing facilities, a national requirement to retrofit existing open-cycle with closed-cycle systems (i.e., cooling towers) would not be a cost-effective approach, and at many existing facilities, retrofits may not even be possible. USEPA estimated that the total capital costs for individual high-flow plants (i.e., $>2$ billion gallons per day) to convert to wet cooling towers generally ranges from $\$ 130$ to $\$ 200$ million, with annual operating costs in the range of $\$ 4$ to $\$ 20$ million [NPDES Final Regulations to Establish Requirements for Cooling Water Intake Structures at Phase II Existing Facilities 40 CFR Parts 9, 122 et al., Fed. Reg., Vol. 69(131), pp. 41576-41693]. When these costs are compared to the value of the fish that would not be entrained or impinged, it becomes clear that other compliance strategies need to be considered. This is valuable information for the study sponsors, not only because the information can be used to justify alternate compliance strategies but because it can also be used as the basis for evaluating various intake technologies.

\section{Intangible benefits}

While the financial value of participating in this longterm fish monitoring study has been demonstrated, there are other benefits realized by the participants. In addition to the financial, regulatory, and technical value of the program, there is a societal benefit, not only to the participants but also to the resource managers with whom the data are shared. As mentioned earlier, the annual ORERP reports are shared with resource agencies in the Ohio River states. A summary of the results that have been obtained over the past 40 years provides specific illustrations of how the program can be of value to Ohio River fishery managers. From 1970 through 2009, 130 fish species were collected (EPRI 2012a, b). A group of the same 30-40 species are collected every year, with emerald shiner, channel shiner (Notropis wickliffi), gizzard shad, sauger, bluegill, and freshwater drum typically being the most common within this group. Bowfin (Amia calva), rosyface shiner (Notropis rubellus), chestnut lamprey (Ichthyomyzon castaneus), and muskellunge (Esox masquinongy), while interesting species, are rarely collected. As of 2009, 16 state listed species have been collected. Understanding the population trends of various species within the river can help fishery managers develop better management plans.

The results of the research program have also been used in the development of a compendium on the reproductive biology and early life ecology of fish in the Ohio River Basin. Data from the ORERP field collections, as well as that from other field studies, were used to create an illustrated resource document for biologists who study the reproductive biology and early life history of fish species that occur in the river. The result of this work is a series of volumes covering the major fish families in the river (Wallus et al. 1990; Kay et al. 1994; Simon et al. 2000; Simon and Wallus 2006; Wallus and Simon 2006). The ORERP technical reports are referenced throughout these volumes, indicating once again, the value of the program.

\section{How long is long enough?}

One question that repeatedly comes up when requesting funding for a long-term monitoring program is, "How long is long enough?" or "When will you be done?" Several researchers have reflected on this and have based their conclusions on very sound technical information. For example, in their paper on the long-term shifts in the species composition of a coastal fish community, Collie et al. (2008) noted that fish populations vary on temporal scales ranging from interannual to millennial! They studied data on 25 fish and invertebrate species collected from Narragansett Bay, RI, USA, from 1959 through 2005 and found that over the 47 year period, the community shifted from vertebrates to invertebrates and, especially since 1980 , from benthic to pelagic species (Collie et al. 2008). They found that the shifts in species composition correlated most strongly with spring-summer sea surface temperatures, which increased $1.6^{\circ} \mathrm{C}$ during the study period.

Thomas (2005) found that studies should be at least as long as the lifespan of large-bodied fish in the waterbody being studied. Since freshwater drum as old as 18 years have been collected from the Ohio River, it appears that these studies should be conducted minimally over a period of 20-25 years. The definition of "long term" depends on the time scale of the ecological process being studied and often, it is typically decades. In 
her analysis of four river systems, Thomas (2005) found that "sampling the aquatic community of a river or a site once does not provide sufficient information to assess the community status." Thomas (2005) also found that long-term studies provide a more accurate analysis of ecosystem structure than short-term studies.

Monitoring studies are often considered to be "unscientific," but they are actually very valuable relative to the resource they protect. According to Lovett et al. (2007), "Good, long-term monitoring records are rare and extremely valuable," but it is still necessary to balance data requirements with available economic resources and data should always be collected with a testable prediction in mind. Such an assessment is done for the ORERP on an annual basis during the annual meeting held among the participating companies. Often, the discussion centers on how to establish minimum sampling requirements so that during periods when economic resources are limited; the value of the database is not compromised by a quick decision to discontinue or severely limit the monitoring program. Other discussions center on how to collaborate with other organizations that conduct fish monitoring programs on the river. This would include the ORSANCO, the Ohio Environmental Protection Agency, the Indiana Department of Natural Resources, and local universities and colleges. These organizations also feel the strain of limited financial resources and collaboration offers one way to maintain worthwhile monitoring programs.

\section{Summary}

Without long-term monitoring programs, population evaluations may incorrectly indicate adverse impacts where none exist or no impact where one is likely to occur. New environmental regulations, such as those written in response to $\S 316$ (b) of the Clean Water Act, often require that the best technology available be used to minimize potential adverse environmental impacts to fish populations. Inadequate studies could lead to costly mistakes with regards to technology installations. The ORERP has been in existence for over 40 years and the long-term nature of the program has allowed for the establishment of aquatic community indices to support evaluations of technology performance, the collaborative development of compliance metrics, and the assessment of fish population trends. These studies have concluded that the Ohio River fish community has improved in response to improved water quality and that power plant fish entrainment and impingement has had little or no measureable impact. Through collaboration and the use of long-term data, $\$ 6.3$ million in monitoring costs were saved during recent fish impingement studies. Benefit valuations have also demonstrated that the value of the fish protected by the installation of new cooling water intake technologies is dwarfed by the cost of installing that technology. The benefits of a long-term fish monitoring program go beyond financial and regulatory benefits and include technical and societal benefits as well, such as sharing the information with state and federal agencies who are also assessing the river's fish populations. The annual cost of participating in such programs is clearly justified when weighed against the potential costs of not having the long-term data when it is needed most.

Open Access This article is distributed under the terms of the Creative Commons Attribution License which permits any use, distribution, and reproduction in any medium, provided the original author(s) and the source are credited.

\section{References}

Barnthouse, L. W., Klauda, R. J., Vaughan, D. S., Kendall, R. L. (Eds.) (1988). Science, law, and Hudson River power plants: A case study in environmental impact assessment. American Fisheries Society, Monograph 4. Bethesda: American Fisheries Society.

Barnthouse, L.W. (2013). Impacts of entrainment and impingement on fish populations: A review of the scientific evidence. Environmental Science \& Policy 31, 149-156.

Bolgrien, D. W., Angradi, T. R., Schweiger, E. W., \& Kelly, J. R. (2005). Contemplating the assessment of great river ecosystems. Environmental Monitoring and Assessment, 103, 5-20.

Carpenter, S. R. (1998). The need for large scale experiments to asses and predict the response of ecosystems to perturbation. In M. L. Pace \& P. M. Groffman (Eds.), Successes limitations, and frontiers in ecosystem science (pp. 287312). New York: Springer.

Collie, J. S., Wood, A. D., \& Perry, H. (2008). Long-term shifts in the species composition of a coastal fish community. Canadian Journal of Aquatic Sciences, 65, 1352-1365.

Coutant, C. C. (1992). Testing the waters. Electric Perspectives. July/August, 32-40.

Daniels, R. A., Limburg, K. E., Schmidt, R. E., Strayer, D. L., Christopher-Chambers, R. (2005). Changes in fish assemblages in the tidal Hudson River in Large River, New York. In J.N. Rinne, R.M. Huges, B. Calamusso (Eds), Historical changes in large river fish assemblages of the Americas (pp. 471-489). Amer. Fish. Soc. Symp. 45.

Danila, D. J. (2000). Estimating the abundance and egg production of spawning winter flounder (Pseudopleuronectes 
americanus) in the Niantic River, CT for use in the assessment of impact at Millstone Nuclear Power Station. Environmental Science and Policy, 3, S459-S469.

EA (2004). 2003 Ohio River Ecological Research Program. Final Report. Deerfield: EA Engineering, Science and Technology, Inc.

Eisele, P.J., \& Malaric, J.F. (1978). A conceptual model of causal factors regarding gizzard shad runs at steam electric power plants. In L.D. Jensen (Ed). Fourth National Workshop on Entrainment and Impingement (pp. 291-298). Melville: EA Communications

Elliot, J. M. (1990). The need for long-term investigations in ecology and the contribution of the Freshwater Biological Association. Freshwater Biology, 23, 1-5.

Emery, E. B., Simon, T. P., McCormick, F. H., Angermeier, P. L., Deshon, J. E., Yoder, C. O., Sanders, R. E., Person, W. D., Hickman, G. D., Reash, R. J., \& Thomas, J. A. (2003). Development of a multimetric index for assessing the biological condition of the Ohio River. Transactions of the American Fisheries Society, 132, 791-808.

EPRI (2006). Ohio River Ecological Research Program: Economic benefit valuation of reductions in impingement at a hypothetical cooling water intake on the Ohio River. EPRI Report 1014337. Electric Power Research Institute, Palo Alto. www.epri.com.

EPRI (2007). Ohio River Ecological Research Program (ORERP): 2005 Ohio River monitoring results. EPRI Report 1015422. Electric Power Research Institute, Palo Alto. www.epri.com.

EPRI (2008a). Proceedings: Second Thermal Ecology and Regulation Workshop: October 2-3, 2007. EPRI Report 1016809. Electric Power Research Institute, Palo Alto. www.epri.com.

EPRI (2008b). Ohio River Ecological Research Program (ORERP): 2006 Ohio River monitoring results. EPRI Report 1017002. Electric Power Research Institute, Palo Alto. www.epri.com.

EPRI (2009a). Ohio River Ecological Research Program (ORERP): 2007 Ohio River monitoring results. EPRI Report 1019550. Electric Power Research Institute, Palo Alto. www.epri.com.

EPRI (2009b). Ohio River Ecological Research Program: Impingement mortality characterization study at 15 power stations. EPRI Report 1018540. Electric Power Research Institute, Palo Alto. www.epri.com.

EPRI (2011). Ohio River Ecological Research Program (ORERP): 2008 Ohio River monitoring results. EPRI Report 1021540. Electric Power Research Institute, Palo Alto. www.epri.com.

EPRI (2012a). Ohio River Ecological Research Program: 2009 Ohio River monitoring results. EPRI Report 1024821. Electric Power Research Institute, Palo Alto. www.epri.com.

EPRI (2012b). Ohio River Ecological Research Program: 2010 Ohio River monitoring results. EPRI Report 1025093. Electric Power Research Institute, Palo Alto. www.epri.com.

Franklin, J. F. (1989). Importance and justification of long-term studies in ecology. In G. E. Likens (Ed.), Long-term studies in ecology (pp. 3-19). New York: Springer.
Fremling, C.R., Rasmussen, J.L., Sparks, R.E., Cobb, S.P., Bryan, C.F., Claflin, T.O., (1989). Mississippi River fisheries: A case history. In D.P. Dodge (Ed.), Proceedings of the International Large River Symposium. Can. Spec. Publ. Fish. Aquat. Sci. 106 (pp. 309-351).

Gammon, J. R., \& Simon, T. P. (2000). Variation in a great river index of biotic integrity over a 20 -year period. Hydrobiologia, 422/423, 291-304.

Hickman, G. D., \& Brown, M. L. (2002). Proposed methods and endpoints for defining and assessing adverse environmental impact (AEI) on fish communities/populations in Tennessee River reservoirs. The Scientific World Journal, 2(S1), 204-218.

Hickman, G.D., \& Olmsted, L.L. (2001). Performance of the Reservoir Fish Assemblage Index (RFAI) in Catawba and Cumberland River Reservoirs. Final Report to Electric Power Research Institute (43 pp.).

Jacobson, P.M., Dixon, D.A., Leggett, W.C., Marcy, B.C., Jr., Massengill, R.R., (2004). The Connecticut River Ecological Study (1965-1973) revisited: Ecology of the Lower Connecticut River 1973-2003. American Fisheries Society. Monograph 9, Bethesda.

Jennings, M. J., Fore, L. S., \& Karr, J. R. (1995). Biological monitoring of fish assemblages in Tennessee Valley reservoirs. Regulated Rivers, 11, 263-274.

Johnson, M. G., \& Brinkhurst, R. O. (1971). Associations and species diversity in benthic macroinvertebrates of Bay of Quinte and Lake Ontario. Journal of the Fisheries Research Board of Canada, 28(11), 1683-1697.

Kay, L. K., Wallus, R., \& Yeager, B. L. (1994). Reproductive biology and early life history of fishes in the Ohio River drainage. Volume 2: Catostomidae. Chattanooga: Tennessee Valley Authority.

King, R. G., Seegert, G. L., \& Vondruska, J. T. (2010). Factors influencing impingement at 15 Ohio River power plants. North America Journal of Fisheries Society, 30, 11491175 .

Langford, T. E. L. (1990). Ecological effects of thermal discharges. New York: Elsevier.

Lindenmayer, D. B., Likens, G. E., Andersen, A., Bowman, D., Bull, C. M., Burns, E., Dickman, C. R., Hoffmann, A. A., Keith, D. A., Liddell, M. J., Lowe, A. J., Metcalfe, D. J., Phinn, S. R., Russell-Smith, J., Thurgate, N., \& Wardle, G. M. (2012). Value of long-term ecological studies. Austral Ecology, 37, 745-757. doi:10.1111/j.1442-9993.2011.02351.x.

Lohner, T. W., Seegert, G. L., Vondruska, J. T., \& Perry, E. (2000). Assessment of 316(b) impacts on Ohio River fish populations. Environmental Science and Policy, 3, S249-S259.

Lovett, G. M., Burns, D. A., Driscoll, C. T., Jenkins, J. C., Mitchell, M. J., Rustad, L., Shanley, J. B., Likens, G. E., \& Haeuber, R. (2007). Who needs environmental monitoring? Frontiers in Ecology and the Environment, 5(5), 253-260.

McClelland, M. A., Sass, G. G., Cook, T. R., Irons, K. S., Michaels, N. N., O’Hara, T. M., \& Smith, C. S. (2012). The long-term Illinois River fish population monitoring program. Fisheries, 37(8), 340-350.

Nielsen, L. A., Sheehan, R. J., \& Orth, D. J. (1986). Impacts of navigation on riverine fish production in the United States. Polish Archives of Hydrobiology, 33, 277-294.

NRC (1990). Managing troubled waters: The role of marine environmental monitoring. Committee on a 
Systems Assessment of Marine Environmental Monitoring. Washington: National Research Council, National Academy Press.

O'Hara, T.M., M. A. McClelland, K.S. Irons, T.R. Cook, and G.G. Sass. (2008). Effect of recently completed habitat rehabilitation and enhancement projects on fish abundances in La Grange Pool of the Illinois River using long-term resource monitoring program data. U.S. Geoligical Survey, Upper Midwest Environmental Sciences Center, LTRMP Technical report, 2008-T001, LaCrosse, Wisconsin.

OEPA. (1989). Biological criteria for the protection of aquatic life, Vol. III, Standardized biological field sampling and laboratory methods for assessing fish and macroinvertebrate communities. Columbus: Ohio Environmental Protection Agency.

Pegg, M. A., \& McClelland, M. A. (2004). Spatial and temporal patterns in fish communities along the Illinois River. Ecology of Freshwater Fish, 13, 125-135.

Perry, E., Seegert, G. L., Vondruska, J. T., Lohner, T. W., \& Lewis, R. (2002). Modeling possible cooling-water intake system impacts on Ohio River fish populations. The Scientific World Journal, 2(S1), 58-80.

Rao, J. N. K. (2003). Small area estimation. New York: Wiley.

Sanders, R. E. (1991). Day versus night electrofishing catches from near-shore waters of the Ohio and Muskingum Rivers. Ohio Journal of Science, 92, 51-59.

Simon, T. P., \& Wallus, R. (2006). Reproductive biology and early life history of fishes in the Ohio River drainage. Volume 4: Percidae. Boca Raton: CRC.

Simon, T. P., Kay, L. K., \& Wallus, R. (2000). Reproductive biology and early life history of fishes in the Ohio River drainage. Volume 3: Ictaluridae. Boca Raton: CRC.

Thomas, J. F. (2005). How long should a long-term river study be? Journal of Freshwater Ecology, 20(2), 367-379.

Thomas, J.A., Emery, E.B., McCormick, F.H., (2005). Detection of temporal trends in Ohio River fish assemblages based on lockchamber surveys (1957-2001). In J.N. Rinne, R.M.
Hughes, B. Calamusso, et al. (Eds.), Historical changes in large river fish assemblages of the Americas (pp. 431449). Amer. Fish. Soc. Symp. 45.

Tinkle, D. W. (1979). Long-term field studies. BioScience, 29(12), 717.

US EPA (2009). Steam electric power generating point source category: Final detailed study report. EPA 821-R-09-008, October. Washington.

USGS (1999). Ecological status and trends of the Upper Mississippi River System 1998: A report for the Long Term Resource Monitoring Program. US Geological Survey, Upper Midwest Environmental Sciences Center, La Crosse, WI. April 1999. LTRMP 99-T001 (236 pp).

Van Hassel, J. H., Reash, R. J., Brown, H. W., Thomas, J. L., \& Mathews, R. C., Jr. (1988). Distribution of upper and middle Ohio River fishes, 1973-1985: I. Associations with water quality and ecological variables. Journal of Freshwater Ecology, 4(4), 441-458.

Wallus, R., \& Simon, T. P. (2006). Reproductive biology and early life history of fishes in the Ohio River drainage. Volume 5: Aphredoderidae through Cottidae, Moronidae and Sciaenidae. Boca Raton: CRC.

Wallus, R., Simon, T. P., \& Yeager, B. L. (1990). Reproductive biology and early life history of fishes in the Ohio River drainage. Volume 1: Acipenseridae through Esocidae. Chattanooga: Tennessee Valley Authority.

Walters, C. J., \& Martell, S. J. D. (2004). Fisheries ecology and management. Princeton: Princeton University Press.

WAPORA, Inc (1971). The effect of temperature on aquatic life in the Ohio River. Final Report, July, 1970-September, 1971 (151 pp.).

WAPORA, Inc (1974). Continuing ecological studies of the Ohio River 1973. Final Report.

WAPORA, Inc (1978). Temporal and spatial distribution patterns of adult and larval fish. Final Report, June 1978 (152 pp.).

Wisniewski, J. (2000). Power plants \& aquatic resources: Issues and assessment. Environmental Science and Policy, 3(1), $\mathrm{S} 1-\mathrm{S} 512$. 